\title{
Frequency of cutaneous manifestations in drug abuse patients.
}

1. MBBS, FCPS

Associate Professor Dermatology Sahiwal Medical College, Sahiwal. 2. MBBS, FCPS

Assistant Professor Psychiatry Sahiwal Medical College, Sahiwal. 3. MBBS, FCPS

Associate Professor Pathology Shalamar Medical and Dental College, Lahore.

Corresponding Address: Dr. Zahid Rafiq Department of Dermatology Sahiwal Medical College, Sahiwal. drzahid80@hotmail.com

Article received on: 17/08/2020

Accepted for publication: 08/10/2020

\section{Zahid Rafiq ${ }^{1}$, Syed Muntazir Mehdi', Urfa Shafi ${ }^{3}$}

ABSTRACT... Objective: Drug abuse and drug addiction cases have been increased immensely in last few decades in Pakistan. This study was conducted to assess the frequency of cutaneous manifestations in drug abuse patients. Study Design: Cross Sectional study. Settings: Dermatology Department of a DHQ Teaching Hospital/Sahiwal Medical College, Sahiwal and Central Jail Hospital, Sahiwal. Period: November 2019 to June 2020. Material \& Methods: 50 patients with drug abuse irrespective of age and gender were selected. Skin manifestations based on history and examination recorded on predesigned proforma. Laboratory investigations and skin biopsies were performed to confirm diagnoses in doubtful cases. Results: A total of 50 male patients with age above 16 years were enrolled. Single drug addiction was noticed in $62 \%(n=31)$ and polydrug abuse was observed in $38 \%(n=19)$. Regarding mode of drug intake, single and multiple modes of drug administration were seen in equal number $50 \%(n=25)$ each. Major bulk of skin manifestations were chronic including skin scars $66 \%(n=33)$, xerosis $60 \%(n=30)$, hyperpigmentation $58 \%(n=29)$, oral mucosal changes $94 \%(n=47)$ and facial skin changes $60 \%(n=30)$. Acute along with chronic skin changes were observed in $30 \%(n=15)$ mainly including injection marks $30 \%(n=15)$, vascular changes $12 \%$ $(n=6)$ and infections $8 \%(n=4)$. Conclusion: Skin scars, xerosis, hyperpigmentation and oral mucosal changes are the common skin changes observed among drug abusers. Thus, physicians need to be aware of skin signs of drug abuse for timely recognition of substance abuse disorders and effective management.

Key words: $\quad$ Cutaneous Manifestations, Chronic Skin Changes, Drug Abuse.

Article Citation: Rafiq Z, Mehdi SM, Shafi U. Frequency of cutaneous manifestations in drug abuse patients. Professional Med J 2021; 28(4):497-503.

https://doi.org/10.29309/TPMJ/2021.28.04.5998

\section{INTRODUCTION}

Skin is considered to be mirror image of the body; we can establish diagnosis of systemic diseases or disease involving any organ of the body by looking into skin and mucus membranes. This principle or assumption could be applied in suspected cases of drug abuse or drug addiction by cutaneous and mucosal findings. It is estimated that alcohol and illicit drug addiction contributes $1.5 \%$ of global disease burden and it is higher (5\%) in developed countries like in USA. ${ }^{1}$ Worldwide, drug abuse is common among young people aged between 14-25 years + but in Pakistan peak age of drug abuse ranges from 25 to 39 years. Drug abuse number has increased in the last few decades and according to UNDCO survey report 2013 about $6 \%$ of the population use illicit drugs. $^{2}$
Multiple factors including genetic, social, psychological and environmental have been postulated in the etiology of drug abuse. ${ }^{3}$ Studies have shown that there may be gene inheritance which can be involved in susceptibility to drug abuse, but exact mechanism of gene regulating physical reaction to these addictive drugs is still unknown. ${ }^{4}$ Different neurophysiological pathways have been implicated in multiple neuropsychiatric conditions including substance addiction. ${ }^{5}$ Environmental factors such as history of sexual abuse during childhood, poor relationship with family especially with parents, peer pressure and poor social skills may considered as contributing factors for drug abuse. Other factors pertaining to community included poverty, poor living conditions, illiteracy, and lack of recreational facilities at home were identified. ${ }^{6}$ 
Different drugs used for addiction are opioids (heroin, opium), cannabis derivatives (hashish, marijuana), cocaine, alcohol, Amphetamine, Lysergic acid diethylamide acid (LSD), ecstasy, anabolic steroids and inhalants. Their numbers may vary in different regions of the world due to availability and demographic reasons. ${ }^{7}$ Different modes of drug intake in drug abusers are ingestion, inhalation, injections, sniffing, snorting and transdermal. ${ }^{8}$ As with standard dose, the use of any drug have psychological as well as systemic effects on body, so drug abuse may have more severe social and systemic effects affecting the different organs of body including the skin. Thus mucocutaneous findings may be helpful in diagnosing the suspected case of drug abuse. $^{9}$

Physicians and dermatologists must know the important cutaneous signs of drug abuse so that before history taking they can have clues to establish diagnosis of cutaneous manifestations resulting from drug abuse. Moreover, its importance is due to fact that most of the addicts and their attendants hide information on first encounter with doctor due to social stigmata. It had been observed in the previous studies that majority of patients seeking treatment in medical clinic for drug addictions had skin manifestations due to drug abuse. ${ }^{10}$ The rationale of carrying out this study was to identify cutaneous findings related to drug abuse especially in chronic skin lesions which may have severe implications on human body if not treated timely.

\section{METERIAL \& METHODS}

This cross-sectional study was conducted in Department of Dermatology at DHQ/GHAQ Teaching Hospital /Sahiwal Medical College, Sahiwal and addiction unit, Central Jail Hospital, Sahiwal from November, 2019 to June, 2020 after approval from ethical review committee and Superintendent Central Jail, Sahiwal. A total of 50 drug abuse patients of either sex and age of more than 16 years were selected. An informed consent was taken from each patient. Demographic variables and clinical data were noted on predesigned proforma. After a detailed history, cutaneous and systemic examination was carried out. Routine laboratory tests and skin biopsy was conducted in suspicious cases. Data was analyzed by SPSS Version 25.

\section{RESULTS}

In this study, 50 male patients of drug abuse history were included. Majority of study patients $44 \%(n=22)$ belong to age group 25-35 years with mean age of 31 years. (Table-I) Duration of addiction and duration of cutaneous lesions was more than five years in most of study patients $68 \%(n=34)$ and 58\% $(n=29)$ respectively. (Table-II) Majority of study patients $62 \%(n=31)$ were married. In this study, laborers $24 \%(n=12)$, farmers $22 \%(n=11)$ employed $22 \%(n=11)$ were top three occupations among drug abusers followed by self-employed $16 \%(n=8)$ and drivers $16 \%(n=8)$.

The study result revealed that single drug addiction $62 \%(n=31)$ was more frequent than polydrug abusers $38 \%(n=19)$. Distribution of patient according to type of drug is shown in Table-III.

Single and multiple mode of drug administration were observed in equal number of patients $50 \%$ $(n=25)$. Distribution of patient according to mode of drug intake is depicted in Table-IV. The commonest site for cutaneous manifestations were limbs $(n=36)$ followed by face $(n=32)$ and trunk $(n=21)$.

\begin{tabular}{|l|c|c|}
\hline \multicolumn{1}{|c|}{ Age (years) } & No & Percentage \\
\hline$<25$ & 13 & $26 \%$ \\
\hline $25-35$ & 22 & $44 \%$ \\
\hline$>35$ & 15 & $30 \%$ \\
\hline Mean \pm SD & & $31.72 \pm 9.39$ \\
\hline Table-I. Distribution of patients according to age \\
\hline
\end{tabular}




\begin{tabular}{|l|c|c|c|}
\hline & $\begin{array}{c}\text { Duration } \\
\text { (in years) }\end{array}$ & $\begin{array}{c}\text { No of } \\
\text { Patients }\end{array}$ & Percentage \\
\hline \multirow{2}{*}{$\begin{array}{l}\text { Duration of } \\
\text { Addiction }\end{array}$} & $<2$ & 2 & 4 \\
\cline { 2 - 4 } & $2-5$ & 14 & 28 \\
\hline \multirow{2}{*}{$\begin{array}{l}\text { Duration of } \\
\text { cutaneous }\end{array}$} & $>5$ & 34 & 68 \\
\hline lesions & $1-2$ & 4 & 8 \\
\hline & $2-5$ & 10 & 14 \\
\hline
\end{tabular}

Table-Il. Distribution of patients according to duration of addiction and cutaneous lesions $(n=50)$

\begin{tabular}{|c|c|c|c|}
\hline $\begin{array}{c}\text { Type of Drug } \\
\text { Abuse }\end{array}$ & $\begin{array}{l}\text { Name of } \\
\text { Drug }\end{array}$ & $\begin{array}{c}\text { No of } \\
\text { Patients }\end{array}$ & Percentage \\
\hline \multirow{2}{*}{ Opioids } & Heroin & 17 & 34 \\
\hline & Afeem & 9 & 18 \\
\hline \multirow{2}{*}{ Cannabinoids } & Charas & 2 & 4 \\
\hline & Hashish & 1 & 2 \\
\hline Alcohol & & 2 & 4 \\
\hline others & & 0 & 0 \\
\hline \multirow{4}{*}{$\begin{array}{l}\text { Multiple drug } \\
\text { abuse }\end{array}$} & $\begin{array}{l}\text { Charas \& } \\
\text { Herion }\end{array}$ & 10 & 20 \\
\hline & $\begin{array}{l}\text { Charas \& } \\
\text { Afeem }\end{array}$ & 7 & 14 \\
\hline & $\begin{array}{l}\text { Heroin \& } \\
\text { Hashish }\end{array}$ & 1 & 2 \\
\hline & $\begin{array}{l}\text { Charas, } \\
\text { Afeem \& } \\
\text { Heroin }\end{array}$ & 1 & 2 \\
\hline Total & & 50 & 100 \\
\hline
\end{tabular}

Table-III. Distribution of patient according to type of drug

Skin changes resulting from drug abuse were categorized into acute and chronic manifestations. Among acute cutaneous changes of drug abuse, injection marks were seen in 30\% $(n=15)$, vascular complications in $16 \%(n=8)$, infections in $8 \%(n=4)$, vasculitis in $8 \%(n=4)$ of study subjects. Infection which were observed in the study included cellulitis, subcutaneous abscess and necrotizing ulcer. Different vascular complications recorded were thrombophlebitis $12 \%(n=6)$, cutaneous necrosis $2 \%(n=1)$ and gangrene $2 \%(n=1)$. Vasculitis was seen in study objects with most common form was pyoderma gangrenosum. Urticaria was observed only in one of the patient.

\begin{tabular}{|c|c|c|c|}
\hline $\begin{array}{c}\text { Mode of } \\
\text { Drug Abuse }\end{array}$ & $\begin{array}{c}\text { Mode of } \\
\text { Drug Abuse }\end{array}$ & $\begin{array}{c}\text { No of } \\
\text { Patients }\end{array}$ & Percentage \\
\hline \multirow{6}{*}{ Single mode } & Inhalational & 7 & 14 \\
\hline & Oral & 6 & 12 \\
\hline & Smoking & 4 & 8 \\
\hline & Intravenous & 3 & 6 \\
\hline & Snuffing & 3 & 6 \\
\hline & Drinking & 2 & 4 \\
\hline \multirow{6}{*}{$\begin{array}{l}\text { Multiple } \\
\text { mode }\end{array}$} & $\begin{array}{l}\text { Inhalational, } \\
\text { Smoking }\end{array}$ & 12 & 24 \\
\hline & $\begin{array}{l}\text { Inhalational, } \\
\text { Smoking, } \\
\text { Intravenous }\end{array}$ & 5 & 10 \\
\hline & $\begin{array}{l}\text { Intravenous, } \\
\text { Inhalational }\end{array}$ & 3 & 6 \\
\hline & $\begin{array}{l}\text { Inhalational, } \\
\text { Smoking, } \\
\text { Oral }\end{array}$ & 2 & 4 \\
\hline & $\begin{array}{l}\text { Intravenous, } \\
\text { Oral }\end{array}$ & 2 & 4 \\
\hline & $\begin{array}{l}\text { Intravenous, } \\
\text { Smoking }\end{array}$ & 1 & 2 \\
\hline
\end{tabular}

Table-IV. Distribution of patient according to mode of drug intake

Current study result showed that skin scars, xerosis, hyperpigmentation and oral mucosal changes were major chronic cutaneous manifestations among drug abuse patients. Different variety of skin scars including atrophic scars $30 \%(n=15)$, post cigarette burns scars $6 \%(n=3)$, hypertrophic scars $2 \%(n=1)$ and keloid $2 \%(n=1)$ were found mainly on limbs and trunk in patients using smoking as mode of drug intake. Skin popping scars $26 \%(n=13)$, linear scars with woody fibrous tract along limb vessel $16 \%(n=8)$ were observed in intravenous drug abusers. Striae were observed in $20 \%(n=10)$ of patient with smoking and intravenous mode of drug intake mainly on lower abdomen and thigh.

Xerosis of skin including limbs and trunk were observed in $62 \%(n=31)$ of patients. Hyperpigmentation of body was found in $58 \%$ $(n=29)$ of patients. Oral mucosal changes resulting from drug abuse were noted in $94 \%(n=47)$ of study patients. Lips changes included were lip discoloration/pigmentation $44 \%(n=22)$, cheilitis 
$8 \%(n=4)$ and actinic cheilitis $2 \%(n=1)$ mainly seen with smoking mode of drug abuse. Buccal mucosal changes observed were pigmentation $54 \%(n=27)$ and ulceration $24 \%(n=12)$ seen in inhalational, snuffing and smoking mode of drug administration. Teeth discoloration was noted in $30 \%(n=15)$ of patients.

Soft tissue lesions including subcutaneous nodules were found in $22 \%(n=11)$ of patients mainly intravenous drug abusers. Chronic venous insufficiency features with pseudoscleroderma were observed in $2 \%(n=1)$ of patients. Senile facial appearance was noted in half $(50 \%)$ of the patients and facial flushing was observed in $4 \%$ $(n=2)$ of total patients. Nasal erythema within nostril was noted in $36 \%(n=18)$ of patients.

Nail changes were also recorded with different types of drug abuse. Longitudinal ridging (28\%) paronychia (14\%) were commonly seen followed by yellow discoloration (10\%), onychomycosis (6\%), subungual hyperkeratosis (4\%) and clubbing (2\%). Premature greying of hair was noted in one patient.

Different skin disorders observed among drug addicts were dermatitis (4\%), Lichen planus (4\%) and acne vulgaris $(4 \%)$. Kobnerization was also seen in few patients (4\%). Skin drug reactions observed were acneiform eruption (2\%).

\section{DISCUSSION}

Cutaneous changes resulting from drug abuse has been documented in various studies in different parts of the world. These skin manifestations had been found with single and multiple uses of drugs in both genders with variable proportions. Current study enrolled all male patients due to main reason that the study was conducted in drug addiction unit of Central Jail Hospital, Sahiwal where only males were admitted. Secondly very few female patients with drug abuse visit public hospitals in order to get treatment for their skin and other systemic complaints.

Recent study showed that majority of drug abuse patients were in age group 25 to 35 years. This was in concordance with the studies conducted previously. ${ }^{11}$ Duration of drug abuse/addiction was more than 5 years in most of patients. In contrast, different findings regarding duration of drug abuse was demonstrated in studies performed in the past.

Polydrug addiction was more common than single drug abusers in the past studies. ${ }^{12,13,14}$ In current study, single drug users (62\%) were more than poly drug abusers. Similar findings regarding mono drug abusers (62\%) were also observed in the study conducted by Faiza et al in Islamabad. ${ }^{15}$

Recognition of skin changes resulting from drug abuse is important in identifying early complications, thus saving life of these patients. ${ }^{16}$ Acute manifestations of drug abuse in the current study were reported less than previous studies. Skin and soft tissue infections are the most common acute changes observed in drug abusers and considered to be main cause of admission among intravenous drug addicts. ${ }^{10}$ Abscesses and cellulitis the most frequently noted skin and soft tissue infections in drug addicts. Skin pop induces trauma to skin and underlying soft tissue and use of unsterilized needles may help the pathogens like bacteria to enter the human body through skin resulting into cellulitis. ${ }^{17}$ Other infections including subcutaneous abscess, necrotizing ulcer and necrotizing fasciitis were commonly observed in intravenous drug abusers and these may become fetal if not treated early. Extremity infections in intravenous drug abusers may lead to osteomyelitis, and septic arthritis which may cause disability. Thus infections have significant morbidity and mortality in IV drug abuse patients. ${ }^{18,19}$ The low frequency of acute changes especially skin infections in present study were mainly due to selection of partial rehabilitated and treated cases of drug abuse patients in addiction unit of Central Jail Hospital.

Among vascular complications thrombophlebitis was commonly found in present study followed by cutaneous necrosis and gangrene. Necrosis of the extremities is another lethal complication seen in IV illicit drugs. ${ }^{20}$ Vasculitis associated with cocaine reported in various studies are; urticarial vasculitis, retiform purpura, Henoch Schonlein purpura, Raynaud's phenomenon and 
Churg-Strauss Vasculitis. ${ }^{10,17,20,21,22}$ Urticaria is a common skin manifestation observed in heroin addicts in the past studies. It results from mast cell degranulation and mast cell release. Only one patient had urticarial in the present study. ${ }^{17,21}$

In intravenous drug abusers, injection marks or linear track marks develop from damage and sclerosis of the underlying veins. The antecubital fossa veins are most favorite site for IV drug abuse followed by other accessible sites like neck veins, legs (popliteal vein), (inguinal veins)groin, and dorsum of the feet. ${ }^{17}$ Skin popping scars results from self-injections into the subcutaneous tissues and allows direct entry of bacteria and irritants into the skin. This method has the greatest risk factor for acquiring the skin infection among different routes of administration. ${ }^{23,24}$ Roughly $66 \%$ of patients of present study presented with different variety of skin scars. These included atrophic scars, post cigarette burns scars, hypertrophic scars and keloid mainly on limbs and trunk of patients with smoking as mode of drug intake. ${ }^{25}$ Skin popping scars, linear track scars were observed in intravenous drug abusers mainly on limbs.

Generalized xerosis and hyperpigmentation of skin was observed in more than half of the present study cases. Dryness of skin results from environmental or exogenous factors and endogenous factors. Among endogenous causes systemic diseases, chronic infections, endocrine disorders, drugs especially narcotics and heroin has been associated. ${ }^{26}$ Generalized hyperpigmentation of body and at the site of injection has been noted in the literature. ${ }^{10}$

Oral mucosal changes are reported with different modes of drug administration; sniffing, ingesting with food, mucosal application, inhalation and intravenous injection. ${ }^{27}$ Drugs including opiates, amphetamines, miscellaneous hallucinogens, marijuana, and alcohol may produce xerostomia and other changes on lips. ${ }^{28}$ Current study showed lips changes including pigmentation and cheilitis observed among patients who took drugs through smoking and inhalational route. Shekarchizadeh
$\mathrm{H}$ et al from Iran reported oral changes including dental caries, periodontal diseases, mucosal dysplasia, xerostomia, tooth loss among drug abusers. ${ }^{29}$ Buccal mucosal changes including pigmentation and ulceration were noticed in the present study with inhalational, snuffing and smoking mode of drug intake. Leukoplakia and oral submucous fibrosis found with opioids use. Poor oral hygiene practices with chain smoking of tobacco are factors considered to be responsible for these changes seen in drug abuse patients. ${ }^{30}$

Subcutaneous nodules are seen at the site of injection in IV drug abuse. They have tendency to undergo granulamotous change and may result into ulceration. Due to intravenous injections damage occurs to both superficial and deep veins resulting into chronic venous insufficiency and ulceration with sclerosis of the surrounding skin. ${ }^{10}$

Senile facial appearance was observed in majority of study subjects. This finding is seen with use of amphetamine among drug addicts in previous studies. ${ }^{22}$ Facial flushing was observed in patients with alcohol abuse. Cocaine may cause damage to nasal septum and resulting into nasal perforation. ${ }^{17}$ Nasal erythema within nostril was noted in patients with inhalational mode of drug administration.

Eye skin changes may be seen in drug addicts. Cocaine may cause loss of lateral eyebrows (madarosis). ${ }^{17,21}$ Heroine use may lead to periorbital hyperpigmentation. Hair loss and premature greying of hair is noticed in marijuana addicts. ${ }^{17}$

Different dermatoses observed in study patients were dermatitis, Lichen planus and acne vulgaris. Various skin conditions are associated with alcohol abuse include rosacea, psoriasis, seborrheic dermatitis and discoid eczema. ${ }^{17}$ Pemphigus vegetans may occur with heroine abuse. ${ }^{22}$

Illicit drugs may lead to different drug eruptions. Fixed drug eruption, toxic epidermal necrolysis occurs with heroine. Lichenoid drug eruption 
is seen among amphetamine users. ${ }^{22}$ StevensJohnson syndrome may be observed with cocaine and anabolic steroids. ${ }^{21,31}$ Acneiform eruption was observed in study patients. Similar eruptions have been found in the studies of the past. ${ }^{21,22}$

As number of illicit drug abuse patients is growing rapidly, this highlights the need of dermatologists to update the information regarding the already known skin lesions and new emerging skin changes resulting from drug abuse. Moreover, such patients hide information regarding the drug addiction in the history which leads to difficulty in establishing the diagnosis. Recognition of risk factors related with the skin infections of drug abuse is necessary to prevent fatal complications; thereby reducing morbidity among drug addicts. ${ }^{32}$

The major limitation of present study is that data do not represent the real population data or size as it included only few patients presented in OPD Dermatology and mostly consisted of drug abuse patient admitted in addiction unit of Jail Hospital. Secondly, no randomization for selection of patients was done in order to decrease selection bias. Thus variation existed in cutaneous manifestation of drug abuse in our study patients than real population of drug abuse. No female gender in study data is the third evident limitation of this research work.

Current study emphasized that physicians and dermatologists besides getting knowledge of cutaneous clues of drug abuse; they must learn how to motivate such patients to provide their drug related information in history taking so that early diagnosis and appropriate management of skin and systemic problems could be done.

\section{CONCLUSION}

Skin scars, xerosis, hyperpigmentation and oral mucosal changes are the common skin changes observed among drug abusers. Thus, physicians need to be aware of skin signs of drug abuse for timely recognition of substance abuse disorders and effective management.

Copyright@ 08 Oct, 2020.

\section{REFERENCES}

1. Ritchie H, Roser M. Opioids, cocaine, cannabis and illicit drugs. Available from: https://ourworldindata.org/ illicit-drug-use.2018.

2. UNODC, World Drug Report, United Nations office on drugs and crime, Pakistan, 2013. Available from http:// www.undoc.org.pk.

3. Pourallahvirdi M, Rahmani F, Ranjbar F, Ebrahimi Bakhtavar H, Ettehadi A. Major causes of drug abuse from the viewpoint of addicted persons referred to addiction treatment centers of Tabriz City, Iran. Arch Neurosci. 2016; 3(3):e37653.

4. Li MD, Burmeister M. New insights into the genetics of addiction. Nat Rev Genet. 2009; 10(4):225-231.

5. Kim S, Kwok S, Mayes LC, et al. Early adverse experience and substance addiction: Dopamine, oxytocin, and glucocorticoid pathways. Ann N Y Acad Sci. 2017; 1394 (1):74-91.

6. Jadidi N, Nakhaee N. Etiology of drug abuse: A narrative analysis. Journal of addiction. Volume 2014, Article ID 352835, 6 pages.

7. NIDA. Most commonly used addictive drugs. National institute on drug abuse. Available from website.https:// www.drugabuse.gov/publications/media-guide/mostcommonly-used-addictive-drugs. June 25, 2020.

8. Sujatha K, Arundathi T, Rubina S, Ramana BV, Nagarajan G: Drug delivery methods ranking addiction potential. Int J Pharm Sci Res. 2013; 4(4): 1287-1293.

9. Creamer D, Gossop M. Dermatoses induced by illicit drugs. Griffiths C .E.M, Barker J , Bleiker T, Chalmers R , Creamer D. Rook's Textbook of Dermatology. 9TH Edition. UK. Wiley Blackwell: 2016; Pages.3381-84.

10. Kanish B, Bhatia A, Goyal S. Cutaneous complications of injection drug abuse. $J$ of Evolution of Med and Dent Sci. 2014; 3(28): 7755-7762.

11. Batool S, Manzoor I, \& Hassnain S, Bajwa M A Abbas S $M$, Mahamood M \& Sohail $H$. Pattern of addiction and its relapse among habitual drug abusers in Lahore, Pakistan. East Mediterr Health J.2017; 23(3):168-172.

12. Ali $H$, Bushra $R$, Aslam N. Profile of drug users in Karachi City, Pakistan. East Mediterr Health J. 2011; $17(1): 41-45$.

13. Kedia S, Sell MA, Relyea G. Mono- versus polydrug abuse patterns among publicly funded clients. Subst Abuse Treat Prev Policy. 2007 Nov; 8:(2):33. 
14. Niaz U, Siddiqui SS, Hassan S, Husain H, Ahmed S \& Akhter R. A survey of psychosocial correlates of drug abuse in young adults aged 16-21, in Karachi: Identifying 'High Risk' population to target intervention strategies. Pak J Med Sci.2005; 21 (3):27177.

15. Faiza B, Hassan M, Naz S, Naz S. Prevalence and determinants of substance abuse among slum dwellers in Islamabad- Pakistan. ljtmrph 2019; 3(2):107-113.

16. Frank N, Hennings C, Miller J.L. Drug abuse. Kang $\mathrm{S}$, Amagai M, Bruckner A I, Enk A H, Margolis D J, McMichael A J, Orringer J S. Fitzpatrick's Dermatology, 9th Edition, McGraw Hill Education; 2019:pages 170516.

17. Raiker N, Aouthmany M, Ezra N. Dermatologic signs and symptoms of substance abuse. J Clin Exp Dermatol Res.2016; 7(3): 337.

18. Gilbert, A.R., Hellman, J.L., Wilkes, M.S. et al. Self-care habits among people who inject drugs with skin and soft tissue infections: A qualitative analysis. Harm Reduct J.2019; 16:69 .10.1186/s12954-019-0345-z.

19. Tyagi R. Extremity infections in intravenous drug abusers. Arch Clin Microbiol. 2016; 7:3.

20. Wurcel AG, Merchant EA, Clark RP, Stone DR. Emerging and underrecognized complications of illicit drug use. Clin Infect Dis. 2015; 61(12):1840-1849.

21. Gontijo B, Bittencourt FV, Lourenço LFS. Skin manifestations of illicit drug use. An Bras Dermatol. 2006; 81(4):307-17.

22. Hennings, MD, and Jami Mill. Illicit drugs: What dermatologists need to know. J Am Acad Dermatol.2012; 69(1):135-142.
23. Saporito R C, Lopez Pineiro M A, Migden M R, et al. Recognizing skin popping scars: A complication of illicit drug use. Cureus. 2018; 10(6): e2726.

24. Grunebaum A, Skupski D. Skin popping scars - a telltale sign of past and present subcutaneous drug abuse. Case Rep. Perinat. Med. 2012; 1(1-2):37-39.

25. Cather J C, Cather J C. Hypertrophic and atrophic scars. Proc (Bayl Univ Med Cent). 2007 Apr; 20(2):1846.

26. Augustin M, Wilsmann $\square$ Theis D, Körber A, Kerscher M, Itschert G, Dippel M, Staubach P. Diagnosis and treatment of xerosis cutis -a position paper. JDDG. 2018; 16 (Suppl. 4): 3-35.

27. Al Bush MM. An oral cavity profile in illicit- Drug abusers? J Indian Soc Periodontol. 2019; 23(6):517524.

28. Terry D. Rees, D.D.S., M.S.D. Oral effects of drug abuse. Critical Reviews in Oral Biology and Medicine, 1992; 3(3):163-184.

29. Shekarchizadeh H, Khami MR, Mohebbi SZ, Ekhtiari $\mathrm{H}$, Virtanen Jl. Oral health of drug abusers: A review of health effects and care. Iran J Public Health. 2013; 42(9):929-940.

30. Gupta T, Shah N, Mathur VP, Dhawan A. Oral health status of a group of illicit drug users in Delhi, India. Community Dent Health. 2012; 29(1):49-54.

31. Cocca S, Viviano M. Stevens-Johnson syndrome and abuse of anabolic steroids. J Korean Assoc Oral Maxillofac Surg. 2017; 43(1):57-60.

32. Barańska-Rybak W, Błażewicz I, Kąkol M, Roter M, Nowicki R. Cutaneous manifestations of injectable drug use: Hidden secrets. Cutis. 2014; 93(4):185-187.

\begin{tabular}{|c|c|c|c|}
\hline \multicolumn{2}{|c|}{ AUTHORSHIP AND CONTRIBUTION DECLARATION } \\
\hline Sr. \# & Author(s) Full Name & \multicolumn{1}{|c|}{ Contribution to the paper } & Author(s) Signature \\
\hline 1 & Zahid Rafiq & $\begin{array}{l}\text { Final drafting of article, Design } \\
\text { result, Discussion. } \\
\text { Introduction \& review of } \\
\text { literature. } \\
\text { Data analysis, Proof reading, } \\
\text { References correction. }\end{array}$ \\
\hline 3 & Syed Muntazir Mehdi & \\
\hline
\end{tabular}

